Editorial

\title{
Editorial: Access or Excess? Redefining the Boundaries of Transparency in the EU's Decision-Making
}

\author{
Camille Kelbel ${ }^{1, *}$, Axel Marx ${ }^{2}$ and Julien Navarro ${ }^{3}$ \\ ${ }^{1}$ European School of Political and Social Sciences, Lille Catholic University, 59016 Lille, France; \\ E-Mail: camille.kelbel@univ-catholille.fr \\ ${ }^{2}$ Leuven Centre for Global Governance Studies, University of Leuven, 3000 Leuven, Belgium; \\ E-Mail: axel.marx@kuleuven.be \\ ${ }^{3}$ ETHICS EA 7446, Lille Catholic University, 59016 Lille, France; E-Mail: julien.navarro@univ-catholille.fr \\ * Corresponding author
}

Submitted: 21 March 2021 | Published: 31 March 2021

\begin{abstract}
Over the last decades, transparency has featured prominently among the European Union's (EU) efforts to democratize and legitimize its governance. This shift toward transparency has taken many forms and, as the contributions to this thematic issue show, these different forms have evolved significantly over time. Yet, initiatives to enhance transparency have often been blamed for limiting the efficiency of the decision-making process or leading to suboptimal policy outcomes. Consequently, the debate has shifted to whether transparency would be excessive in that it would undermine the EU's capacity to deliver through political arrangements. This editorial presents this transparency-efficiency dilemma, which the different contributions to this thematic issue analyse further.
\end{abstract}

\section{Keywords}

democracy; efficiency; European Union; throughput legitimacy; transparency

\section{Issue}

This editorial is part of the issue "Access or Excess? Redefining the Boundaries of Transparency in the EU's Decision-Making" edited by Camille Kelbel (Lille Catholic University, France), Axel Marx (University of Leuven, Belgium) and Julien Navarro (Lille Catholic University, France).

(C) 2021 by the authors; licensee Cogitatio (Lisbon, Portugal). This editorial is licensed under a Creative Commons Attribution 4.0 International License (CC BY).

\section{Introduction}

Democracy has been the elephant in the room of the European integration project since its inception. Challengers to the qualification of the European Union (EU) as democratic underline both institutional issues, revolving around the lack of accountability of the institutions, and substantive gaps. As the latter is in particular due to the absence of a demos for which remedies are elusive, the EU has overwhelmingly relied on institutional change to address its democratic deficit and foster its democratic ideal. At the same time, the underpinnings of EU democracy have considerably evolved over time, even to the extent of forging ad hoc conceptions of a notion that was thought to be the stronghold of modern polities ('constraining dissensus' and 'throughput legitimacy' being notions which emerged in the wake of the integration project). Over the last decades, a push toward more transparency has featured prominently among the initiatives to enhance the democratic legitimacy of the EU. Commonly defined as allowing citizens to scrutinize all information upon which decisions are made, transparency is at the heart of throughput legitimacy as the only concept that invariably appears in all its definitions (see e.g., Geeraart, 2014; lusmen \& Boswell, 2017; Schmidt, 2013). Step-by-step, different initiatives were hence taken at the supranational level to disclose information and 'open up' the institutions. This "turn towards transparency" (Bianchi \& Peters, 2013) has taken many forms and, as the contributions to the thematic issue 
show, these different forms have evolved significantly over time.

Yet, initiatives to enhance transparency have been found to further influence the efficiency of the decisionmaking process or lead to suboptimal policy outcomes. Transparency is indeed sometimes blamed for slowing the decision-making process and even for hampering its success. There are several reasons underlying this argument. First, when transparency is the rule, decisionmakers may refrain from changing position in the course of negotiations and become inflexible, notably when they receive a clear (and sometimes binding) negotiating mandate from their principal who may thus blame, or even sanction them if they deviate from it (Elster, 2015). Second, by revealing who the 'winners' and 'losers' of negotiation are, transparency increases the cost of defeat. Those on the losing side may be tempted to block decisions or to adopt strategies to conceal their defeat by joining the majority at the last minute, as observed by Novak (2013) in the case of the EU Council of Ministers. Even when transparency and openness do not necessarily create a hurdle to the success of the decision-making process, the argument goes that it creates a disadvantage for the parties engaged in such a collective decision. To disclose one's preferences or negotiating strategy beforehand is indeed likely to weaken one's position, even though it has also been evidenced that greater transparency contributes to increasing the EU's bargaining leverage in international trade negotiations (Heldt, 2020). Third, political actors acting under public scrutiny are compelled to avoid the familiarity and informality which is deemed to facilitate compromises (Fasone \& Lupo, 2015). Last but not least, transparency can fuel increased politicization of policy issues which makes decision-making and implementation more difficult (De Bièvre, Costa, Garcia-Duran, \& Eliasson, 2020). In other words, from an output legitimacy perspective, there might be desirable limits to transparency (Alloa, 2017). As such, the transparency-secrecy dilemma has largely come to epitomise the democraticefficient dilemma. As a consequence, the debate has shifted to whether transparency would be excessive in that it would undermine the EU's almost legendary capacity to deliver through political arrangements. This thematic issue delves into this dilemma.

\section{Outline of the Thematic Issue}

The EU transparency initiatives are indeed often presented as among the most advanced in the world. Elaborated with the explicit aim to act against the common perception of the supranational political system as being distant, technocratic, undemocratic, and even impenetrable, the push toward more transparency was meant to restore accountability and ultimately public trust. Most of the existing literature on transparency has either explored the measures taken to make information on the legislative process more open, or built on its foreseen negative effect on efficiency (Héritier \& Reh, 2012). Some recent studies suggest that major actors are still able to reintroduce informality through the backdoor, controlling whether they dispatch information or not, and circumventing the regulation (Coremans, 2019). This thematic issue builds on this perspective, studying the reaction of institutional actors to the transparency imperatives. The central question addressed by the contributions is: What are the effects of openness and transparency arrangements on the political actors' attitudes and behaviours? As Fung, Graham, and Weil (2007, p. 51) argue, transparency measures aim at steering the behaviour of actors and institutions in ways policy-makers believe will advance the public interest. As such, while some transparency measures may fail to alter behaviours because few actors act on the information generated through the different initiatives, some measures may indeed result in the expected behavioural change. This thematic issue examines the concrete practices of institutions and actors. With different contributions, we hope to provide insight into how and why transparency is 'captured' by institutions and political actors, how it is used, and what potential it has in terms of making the EU more democratic and accountable. To do so, the thematic issue brings together six articles and two commentaries.

The first article by Caby and Frehen (2021) allows us to situate transparency in the wider concern of (throughput) legitimacy, which is nothing less than the raison d'être of the notion. As they note, previous conceptualisations of throughput legitimacy invariably include transparency as one of the concept's dimensions. Within the field, transparency is found to be part of a cluster that deals with how principles are translated into actions within various international organisations, very much in line with this thematic issue's assumption that the focus is now on how actors produce legitimacy and seize its principles. EU studies is also confirmed as a primary subfield (in line with Steffek, 2019).

Subsequent articles delve into transparency developments in reference to specific instruments, actors, and fora. A key instrument to enhance transparency is the EU Transparency Register which emerged out of the European Transparency Initiative and which is discussed in the second contribution by Dinan (2021). It aims to make public which organizations and persons engage with the EU institutions in the policy-making process in order to empower media, civil society, and citizens to scrutinize the conduct of EU officials and to see whether decisions have been influenced in any way by specific interests which do not reflect the public interest. This is possibly an important transparency instrument to steer the behaviour of EU officials. In his contribution, Dinan describes and analyses the emergence, development, and use of the transparency register and identifies several shortcomings to the current approach especially with regard to reaching the general public, media, and citizens. Dinan finds that the current approach results in a register that is mostly used by professionals and lobbyists "clus- 
tered around the European quarter in Brussels" (Dinan, 2021, p. X) and engaged in European public affairs. As a result, the ability of media and other actors to use the register and hold officials to account is significantly hampered. Dinan offers some insights and recommendations to address these concerns.

Sooner or later, the debate on EU transparency almost invariably stumbles on the trilogues as informal meetings where most inter-institutional negotiations are still secretly concluded nowadays, remote from any oversight, except feedback from the negotiators themselves. The third article by Pennetreau and Laloux (2021) addresses this issue empirically by considering the extent to which European Parliament (EP) rapporteurs are being (un)transparent in their speeches when reporting to the assembly's plenary on the legislative compromise they reach through trilogues negotiations. Their investigation is thus a perfect example of looking at transparency in the process. While the plenary speeches are supposed to make up for the intrinsically untransparent nature of trilogues, they evidence that not only is transparency modest but that its degree depends on both the political affiliation and national culture of the rapporteur rather than on political conflicts within the institution or in the inter-institutional arena. In other words, transparency is not particularly prompted by politicisation and political conflicts. Overall, the EP has hence rather failed to deliver on the transparency promise made by the foreseen compensating mechanisms.

In analysing the effects of openness and transparency on attitudes and behaviours of the actors involved it is also relevant to dig into specific policy areas. The fourth contribution by Marx and Van der Loo (2021) focuses on trade policy, which for the last two decades has been under contestation of citizen and civil society actors for being opaque and secret. As a response, the European Commission has put transparency at the forefront of its trade policy as one of its foundational principles, recognizing the importance of transparency for the legitimacy of trade policy. Their article focuses specifically on the negotiation and implementation of a free-trade agreement. Transparency in the context of free-trade agreements relates to different parts of the trade policy process. On the input side, it enables stakeholders to participate in the development of trade agreements and insert different preferences. On the output side, transparency is relevant for holding the actors involved to account for the implementation of the trade agreement. The article shows that the Commission has gone a long way to make the process of negotiating trade agreements much more transparent and in this way enabling the inclusion of different preferences in the negotiation of trade agreements. They are more sceptical about the progress made with regard to the implementation of trade agreements.

The fifth article by Bodson (2021) turns attention to the role of the judiciary. Indeed, transparency in the EUas well as at other levels of governance-cannot rely exclusively on the willingness of the decision-makers to be open and, in particular, to provide access to their files. Judicial institutions can and do play a key role in improving the openness of government and, as such, in shaping the democratic architecture of the political system. As highlighted by Bodson's article, this is precisely what was at stake for the EU with the De Capitani v. European Parliament and the ClientEarth v. European Commission cases, through which the EU Court of Justice ruled in favour of more transparency and openness by imposing the disclosure of internal documents linked to the EU legislative process. However, the capacity of the Court to force transparency is inherently limited as it must act within the remits of the Treaties and the EU primary and secondary laws. What is more, Bodson argues that 'access' as implemented by the Court has to be assessed in light of the risk of the perverse effects of 'excess.' By fixing the borders of transparency, the decisions of the Court may indeed encourage the institutions to shift decision-making away from the formal arenas to informal ones: This is precisely the contrary of what transparency activists wish for.

The final article by Gijsenbergh (2021) focuses on a specific type of actors in the transparency debate, namely whistle-blowers. The progress of transparency may ultimately depend on initiatives of individuals and groups who challenge the institutions to be more open and accountable. This is precisely Gijsenbergh's argument, in his analysis of three whistle-blowers who, over the last 60 years, have had a major impact on how European politicians and officials feel about transparency. By disclosing confidential documents to expose wrongdoings and corruption, these whistle-blowers not only forced transparency upon EU institutions, but also provoked debates about the (il)legitimacy of secrecy and the democratic value of openness. The circumstantiated historical recount of these whistleblowing episodes contributes to demonstrating that recent developments in the EU policy of transparency-notably in the form of the 2019 Directive on the protection of persons who report breaches of Union law-is the culmination of an incremental shift in how democracy is perceived in Europe.

The commentary by Hillebrandt (2021) questions the scope of the 'access' dimension as a fair prerequisite to any consideration on whether transparency comes in excess at the EU level. Asking whether transparency may continue to be reduced to access to documents as the EU has restrictively typified it, Hillebrandt's argument revolves around the changing context that almost naturally facilitates such access. Access to documents is argued to be a mile wide and an inch deep, in that many features of the decision-making process itself remain secluded, that the lay citizen is unlikely to find their way toward such access and the latter is recurrently bypassed, thus echoing the argument about there being a lack of transparency in the process. As such, access to documents as the long-time carrier of the transparency ideal 
does not actually come in excess and has become, in part, unfit for purpose.

The last contribution to the thematic issue takes a more cautious and critical approach to the recent developments of the EU in terms of transparency. In his commentary, Rebasti (2021) indeed ponders the implications of the De Capitani case, also discussed in the contribution by Bodson, for the broader EU model of representative democracy. Echoing the theme of the difficult balance between transparency and efficiency that runs through the entire thematic issue, he contends that the Court's decision to open up the trilogue negotiations' blackbox leaves many questions unanswered as to the nature of the EU legislative process.

\section{Conclusion}

The thematic issue shows that the EU has taken a number of initiatives to make its policy-making process more transparent. Whether these efforts are sufficient to increase the legitimacy of the policy-making process and strengthen accountability mechanisms remains an open question. In a landmark study, Fung et al. (2007) found that many reforms and initiatives for more transparency often generate irrelevant and incomprehensible information for stakeholders who cannot act upon the disclosed information. They stressed the importance for transparency measures to focus on the needs of citizens. Conclusions of the articles collected in this thematic issue point in the same direction: Engaging and involving citizens will be of crucial importance in order to strengthen the legitimacy of the EU. Transparency measures can play an important role in this but they should be designed appropriately and target citizens. This reconnecting to citizens is also highlighted in the launch of the Conference on the Future of Europe which will take place in 2021 and 2022.

\section{Acknowledgments}

This thematic issue was made possible by the EU's Horizon 2020 Research \& Innovation programmeRECONNECT project (Grant Agreement No. 770142).

\section{Conflict of Interests}

The authors declare no conflict of interests.

\section{References}

Alloa, E. (2017). The limits of transparency. Brussels: Koninklijke Vlaamse Academie van België voor Wetenschappen en Kunsten. Retrieved from https://www.kvab.be/sites/default/rest/blobs/ 2095/Final\%20Report\%20Transparency.pdf

Bianchi, A., \& Peters, A. (Eds.). (2013). Transparency in international law. Cambridge: Cambridge University Press.
Bodson, B. (2021). To what extent can the CJEU contribute to increasing the EU legislative process' transparency? Politics and Governance, 9(1), 272-280.

Caby, V., \& Frehen, L. (2021). How to produce and measure throughput legitimacy? Lessons from a systematic literature review. Politics and Governance, 9(1), 226-236.

Coremans, E. (2019). Opening up by closing off: How increased transparency triggers informalisation in EU decision-making. Journal of European Public Policy, 27(4), 590-611.

De Bièvre, D., Costa, O., Garcia-Duran, P., \& Eliasson, L. J. (Eds.). (2020) Politicization of EU trade policy across time and space. [Thematic issue]. Politics and Governance, 8(1), 239-359.

Dinan, W. (2021). Lobbying transparency: The limits of EU monitory democracy. Politics and Governance, 9(1), 237-247.

Elster, J. (2015). Explaining social behavior: More nuts and bolts for the social sciences (2nd ed.). Cambridge: Cambridge University Press.

Fasone, C., \& Lupo, N. (2015). Transparency vs. informality in legislative committees: Comparing the US House of Representatives, the Italian Chamber of Deputies and the European Parliament. Journal of Legislative Studies, 21(3), 342-359.

Fung, A., Graham, M., \& Weil, D. (2007). Full disclosure: The perils and promise of transparency. Cambridge: Cambridge University Press.

Geeraart, A. (2014). New EU governance modes in professional sport: Enhancing throughput legitimacy. Journal of Contemporary European Research, 10(3), 303-321.

Gijsenbergh, J. (2021). From neglect to protection: Attitudes towards whistleblowers in the European institutions (1957-2002). Politics and Governance, 9(1), 281-291.

Heldt, E. C. (2020). Contested EU trade governance: Transparency conundrums in TTIP negotiations. Comparative European Politics, 18(2), 215-232.

Héritier, A., \& Reh, C. (2012). Codecision and Its discontents: Intra-organisational politics and institutional reform in the European Parliament. West European Politics, 35(5), 1134-1157.

Hillebrandt, M. (2021). EU transparency as 'documents': Still fit for purpose? Politics and Governance, 9(1), 292-295.

Iusmen, I., \& Boswell, J. (2017). The dilemmas of pursuing 'throughput legitimacy' through participatory mechanisms. West European Politics, 40(2), 459-478.

Marx, A., \& Van der Loo, G. (2021). Transparency in EU trade policy: A comprehensive assessment of current achievements. Politics and Governance, 9(1), 261-271.

Novak, S. (2013). The silence of ministers: Consensus and blame avoidance in the Council of the European Union. JCMS: Journal of Common Market Studies, 51(6), 1091-1107. 
Pennetreau, D., \& Laloux, T. (2021). Talkin' 'bout a negotiation: (Un)transparent rapporteurs' speeches in the European Parliament. Politics and Governance, 9(1), 248-260.

Rebasti, E. (2021). Return to De Capitani: The EU legislative process between transparency and effectiveness? Politics and Governance, 9(1), 296-299.
Schmidt, V. A. (2013). Democracy and legitimacy in the European Union revisited: Input, output and 'throughput.' Political Studies, 61(1), 2-22.

Steffek, J. (2019). The limits of proceduralism: Critical remarks on the rise of 'throughput legitimacy.' Public Administration, 97(4), 784-796.

\section{About the Authors}

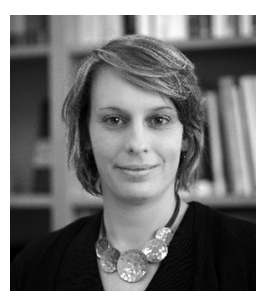

Camille Kelbel is Associate Professor and Head of the academic programmes at ESPOL. As part of her research activities, she is taking part in the Horizon 2020 project 'RECONNECT,' while her research interests more generally lie in issues related to political behaviour, political parties, representation, as well as decision-making processes at the European level. She has published among others in Party Politics, Acta Politica, Political Studies, while her most recent work is to appear in JEPOP.

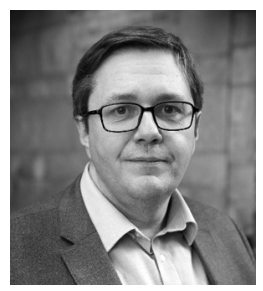

Axel Marx is Deputy Director at Leuven Centre for Global Governance Studies, University of Leuven. His research interests include voluntary sustainability standards, sustainable development, business and human rights, global governance, EU trade policy, and comparative case methods. His publications have appeared in inter alia, European Political Science Review, Political Research Quarterly, Global Policy, Regulation and Governance, World Trade Review, ANNALS of the American Academy of Political and Social Science, International Labour Review and International Journal of Human Rights.

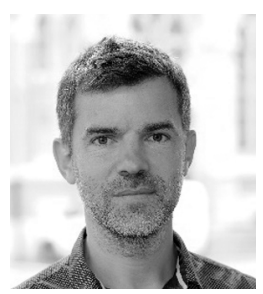

Julien Navarro is Associate Professor of Political Science at Lille Catholic University, affiliated with ETHICS EA 7446. He is also the Francophone Chair of Political Science at the Vienna School of International Studies. His research focuses on parliamentary representation and the politics of the European Union. His most recent articles have appeared in the European Political Science Review, the Swiss Political Science Review, the European Papers and the Journal of Contemporary European Studies. 